\section{Studia}

z Filologii Polskiej
i Stowiańskiej

DOI: $10.11649 /$ sfps.2087
Studia z Filologii Polskiej i Słowiańskiej, 56

Warszawa 2021

Article No. 2087

Citation:

Піддубна, Н. В. (2021). Біблійні антропоніми й топоніми в українській мові: Основні вектори розвитку досліджень. Studia z Filologii Polskiej i Stowiańskiej, 56, Article 2087. https:// doi.org/10.11649/sfps.2087

Piddubna, N. V. (2021). Bibliǔni antroponimy ĭ toponimy v ukraïns'kil movi: Osnovni vektory rozvytku doslidzhen'. Studia z Filologii Polskiej i Słowiańskiej, 56, Article 2087. https://doi.org/10.11649/sfps.2087

\author{
Наталія В. Піддубна \\ (Харківський національний педагогічний \\ університет імені Г. С. Сковороди)
}

\title{
Біблійні антропоніми й топоніми в українській мові: основні вектори розвитку досліджень
}

Релігійні власні назви постійно перебувають у фокусі уваги науковців представників різних галузей мовознавчої науки, зокрема й теолінгвістики. Так, узагальнюючи напрями дослідження взаємодії української мови й релігії, М. Скаб виокремила систему аспектів, де серед основних визначила й функціювання онімів у сфері сакрального (назви релігійних свят, вплив християнства на антропонімійну систему української мови тощо), чому присвячені наукові студії І. Бочарової, М. Лесіва, Л. Осташ, Н. Осташ, I. Фаріон та ін. (Скаб, 2010, с. 6).

Мета статті - з'ясувати основні напрями й особливості розвитку біблійних власних назв в українській мові з огляду на активність їхнього вживання в різних функційних стилях і включення до актуальних мовних процесів.

Чи не найраніше на теренах українського мовознавства в поле зору дослідників потрапили, зокрема, особливості передачі біблійних влас-

This is an Open Access article distributed under the terms of the Creative Commons Attribution 3.0 PL License (creativecommons.org/licenses/by/3.0/pl/), which permits redistribution, commercial and non-commercial, provided that the article is properly cited. (c) The Author(s) 2021.

Publisher: Institute of Slavic Studies, Polish Academy of Sciences

[Wydawca: Instytut Slawistyki Polskiej Akademii Nauk] 
них назв (переважно антропонімів і топонімів) українською мовою, що й відображено в наукових розвідках В. Задорожного (Задорожний, 1998, с. 140), В. Німчука (Німчук, 1993, с. 30), Г. Тимошик (Тимошик, 2009, 2010) та ін.

Не менш активно науковці розробляють питання статусу релігійних, зокрема біблійних, власних назв в ономастичній системі української мови, належності - неналежності того чи того імені до бібліїзмів, що є складним і найбільш дискусійним, оскільки, імовірно, пов’язане з відсутністю чітких критеріїв їхнього виокремлення. Наприклад, на думку К. Безпалової, до бібліїзмів належать не лише прецедентні власні імена, що вживаються переважно як символеми, а й ті власні імена, що наявні в Біблії й використовуються в релігійних текстах у номінативній, а не кваліфікативній функції, у прямому, а не переносному символічному значенні (Безпалова, 2015, с. 15).

На сьогодні лінгвісти звертають усе більшу увагу на те, що власні релігійні назви, активно вживаючись в українській мові, з одного боку, слугують для відображення релігійної картини світу, а з другого - зазнають десакралізації й ресакралізації, що спричинюється до розширення їхнього прагматичного потенціалу, i, відповідно, нерелігійної семантики. Причина цього полягає в тому, що сфери сакрум - антисакрум - профанум $є$ взаємопроникними, як їх, наприклад, розглядає Л. Гонтарук (Гонтарук, 2011, с. 51). Опозиція сакральне - профанне (світське) має динамічний характер, на що вказують дослідники, наприклад Л. Софронова, яка зауважує:

Опозиція сакральне / світське не дається раз і назавжди, межа між її членами постійно змінюється. Те, що в одну епоху перебуває в зоні сакрального, в іншу - опиняється у сфері світській. [...] Коли сакральне в чіткій ізоляції від світського, і обидві сфери культури нібито не перетинають межу, що їх розділяє, вони перебувають у стані відносного спокою. Але у відповідний момент він може порушитися. [...] Тоді змінюються обриси світського. Також сакральне буває готове до того, щоб сприйняти вплив світського. У результаті картина взаємодії світського й сакрального постійно перетворюється (Софронова, 2006, сс. 30-31).

Відповідно, як й інші мовні одиниці, релігійні власні назви можуть зазнавати певних семантичних зсувів, переосмислень, що є наслідком постійної взаємодії сакрального й світського, тобто десакралізації, яку В. Хлебда назвав «сакрум у рамках профанум» (Хлебда, 2001, с. 128). 
Системної десакралізації, за якої, згідно з В. Хлебдою, співвіднесення сакральних одиниць із біблійними стає лише генетичним, а не реальним, коли «джерело їхнє сакральне - Святе Письмо, однак живого почуття цієї сакральності в мовців немає» (Хлебда, 2001, с. 126), зазнають і християнські найменування, зокрема антропоніми й топоніми. Такі одиниці сьогодні сприймають як нейтральні, а «їхня сакральність потенційна й може бути перетворена на сакральність реальну» (Хлебда, 2001, с. 126). Ідеться, очевидно, передусім про імена, що стали невід’ємним складником українського антропонімікону - Іван, Марко, Марія, Анна, Матвій та ін.

На те, що сакральний скрипт індивідуального антропонімічного фрейму, який зазвичай у християн увіходить до найближчого його кола, може поступово відходити від ядра до периферії, звертає увагу й О. Карпенко (Карпенко, 2006).

Доволі часто біблійні імена зазнають власне десакралізації (явної десакралізації), або «сакралізації зі знаком мінус», яку В. Хлебда (Хлебда, 2001, c. 129) розуміє як активізацію вживання сакральних одиниць у текстах, що належать до розширеного тематичного фону, пов'язаного не лише з високими філософськими, екзистенційними, світоглядними проблемами, а й зі злободенними побутовими питаннями, господарством, економікою, торгівлею, компютерами, туризмом тощо. Так, біблійний топонім Вавилон номінує не конкретний населений пункт, а узагальнено позначає гамір, безлад, шум (Коваль, 2012, с. 39), порівн.:

[...] мистецький Вавилон завирував різномов'ям, національними строями, усмішками, творчою напругою, європейськими, східними та азійськими та скандинавськими митияями (3 газети «Дзеркало тижня»);

біблійний антропонім Хам узагальнено називає 'поведінку людей грубих і невихованих, нахабних, жорстоких’ (Коваль, 2012, с. 35). Такі вживання часто межують, з позиції релігійної людини, із богохульством. Ідеться насамперед про «випадки ризикованих порівнянь і профанне вербальне сусідство сакральних мотивів» (Хлебда, 2001, с. 129), порівн.:

- Ми давно живемо, як у раю.

- Що, yсе $\epsilon$ ?

- Та ні, як Адам та Єва голі й босі! (http://www.pravda.com.ua/ - 15.01.10).

Однак вони є однією з питомих ознак української сміхової культури, закоріненої ще у творчості мандрівних дяків, у якій «найвищі біблійні постаті, починаючи від Адама і $є в$, фігурують у раю як близькі зна- 
йомі, розташовуючись поміж простих людей» (Карпенко, 2006, с. 150). О. Карпенко зауважує, що таке десакралізоване вживання імен біблійних героїв у подальшому відіграло вагому роль у розвитку нової української літератури й, відповідно, української мови: «Автори і виконавці таких віршів ведуться з освяченими тисячолітньою традицією біблійними героями як із сусідами, знайомими, переводячи їх з третього в друге коло індивідуального антропонімічного фрейму й поволеньки готуючи грунт для майбутньої „Енеїди“» (Карпенко, 2006, с. 151).

У сучасній українській мові спостерігаються й вияви сполученої ресакралізації, за якої повернення до біблійних образів і мотивів поєднується $з$ національним контекстом, коли ці два контексти органічно зливаються воєдино, а національне начало утворює тему, або рамку; «біблійний образ, що стоїть за використаною фраземою - фокус, або „контейнер“, метафори» (Хлебда, 2001, с. 128), наприклад: Українська Голгофа мовою документів (http://incognita.day.kiev.ua/ukrayinska-golgofa -movoyu-dokumentiv.html) та ін.

Як приклад до сказаного О. Дзера (Дзера, 2017, с. 171) наводить біблійний антропонім Мойсей, який в українській культурі символізує довгоочікуваного провідника нації, що ілюструє поема Мойсей І. Франка і рядки: Воздвигне Вкраӥна / свойого Мойсея (П. Тичина); Не виведе новітній нас Мойсей / На інші ясні зорі й тихі води (І. Жиленко) та ін.

Дослідники виокремлюють таку особливість лексем-бібліїзмів, зокрема й власних назв, як їхню здатність не лише утворювати переносні значення, а й входити до складу фразеологічних одиниць, наприклад: зійти на Голгофу, ветхий Адам, у костюмі Адама і Єви, Хамові діти, іродова душа та ін. (Бабич, 1994; Бетехтина, 1999; Дубровина, 2012).

Російський дослідник О. Солошенко відносить до бібліїзмів анатомічний термін адамове яблуко - 'кадик', уважаючи його таким, що виник під впливом Біблії (Солошенко, 1999, с. 132), тобто має статус оказіонального бібліїзму. В. Мокієнко цей самий термін разом з такими виразами, як виводити вавилони - 'невпевнено, криво йти, перебуваючи в стані алкогольного сп'яніння', співати лазаря - 'прикидаючись нещасним, скаржитися на життя' (див.: Білоноженко et al., 2008, с. 680), адамові слізки - 'горілчані напої' (Білоноженко et al., 2008, с. 667), Мойсеєва дорога - 'Чумацький Шлях', евфемізм потреба ияаря Саула - 'природна потреба (про фізіологічні потреби людини)' та ін. кваліфікує як такі, що пройшли складний і плутаний шлях до сучасного вживання, а їхній зв’я- 
зок із Біблією майже втрачений (Мокиенко, 2014, с. 417). Тому, на думку цього вченого, їх навряд можна вважати бібліїзмами.

Як прецедентні назви біблійні антропоніми й топоніми виявляють свій прагматичний потенціал передусім у художньому стилі, що $\epsilon$ предметом великої кількості наукових розвідок, наприклад: Т. Берест (Берест, 2000), А. Берестової (Берестова, 2016), А. Ковтун (Ковтун, 2011), М. Скаб (Скаб, 2014a, 2014b), Г. Тимошик (Тимошик, 2010) та ін. Однак попри консервативність наукового стилю бібліїзми-антропоніми функціюють і в ньому, поповнюючи галузеві термінології, наприклад, хімічну (фараонові змї та ін.), ботанічну (ієрихонська троянда та ін.), економічну (падший ангел, хрещення вогнем, ефект Йосипа та ін.).

У публіцистичному стилі біблійні власні назви доволі часто вживаються в сильних текстових позиціях заголовків, напр.: Мистецький Вавилон на землі етрусків («Дзеркало тижня», 2004, № 38); Содом і Гоморра: чи готова Україна до виявлення інакшості («День», 2012, № 76); Голгофа Батурина («Україна молода», 2008, № 206) та ін., що $є$ важливим для розуміння тексту статті, оскільки «як специфічний смисловий і психо-соціологічний вузол, ядро ідеї твору заголовок $\epsilon$ ключем до змісту» (Кочан, 2005, с. 129).

Підсиленою експресивністю відзначаються ті заголовки, до складу яких входять бібліїзми-трансформи, зокрема із заміненими біблійними антропонімами чи топонімами. Порівн. назву статті журналіста й телеведучого Ю. Макарова Содом і гангрена («Український тиждень» - 11.01.2018), що присвячена критиці священників, які відмовилися відспівувати померлого хлопчика, хрещеного в іншому обряді.

Зрозуміло, що в наш час уживання бібліїзмів у публічних виступах політиків значно активізувалося. Це демонструють, зокрема, дослідження промов президентів країн (Добош, 2017). Для сучасних ораторів-управлінців Біблія завжди слугуватиме прецедентним текстом, використовуваним для встановлення контакту з населенням, для забезпечення формування позитивного ставлення до тієї чи тієї політичної фігури: «Шляхом такої макростратегії маніпуляції політик одночасно здійснює й приховану стратегію самопрезентації, оскільки він $є$ тим, хто усвідомлює таку „величну надістину“, відповідно, він здатен повести народ „до світлого майбуття“» (Добош, 2017, с. 159).

Наприклад, Президент України П. Порошенко у своїх промовах використав біблійні антропоніми Давид і Голіаб для характеристики сучасної 
війни між Україною й Росією, підбадьорення, переконання в тому, що різниця із супротивником у збройному й економічному потенціалі ще не означає програш слабшого, актуалізуючи біблійну історію про нерівну боротьбу, що завершилася перемогою справедливого Давида, порівн.: Не забуваймо: Давид здолав набагато дужчого Голіафа (Щорічне послання Президента до Верховної Ради - 06.06.2015). Як видається, у такому вживанні біблійний антропонім Давид зазнає сполученої ресакралізації, метафорично актуалізуючи не лише біблійний, а й національний історичний контекст багаторічної справедливої боротьби України за свою незалежність проти сусіда-агресора.

Використовуючись у функції символеми, більшість бібліїзмів-антропонімів і бібліїзмів-топонімів апелятивізується, зберігаючи при цьому біблійні смисли (ірод, каїн, хам, iуда (юда)) (Скаб, 2016, с. 14) і виявляючи дериваційні потенції для репрезентації української мовної картини світу. Наприклад, слово Ірод у сучасній українській мові має не лише пряме номінативне біблійне значення 'Цар Іудеї, якого зображено в Біблії дуже жорстоким', але й похідне, порівн.: «лайл. Дуже жорстока, люта людина, кат, недолюдок» (Бусел, 2009, с. 506). Окрім того, зазначений антропонім утворює дериват - прикметник іродів (іродова душа), що «успадковує» семантику мотиватора. У лексеми актуалізується стилістичне значення «лайл.», тобто висока біблійна тональність нейтралізується, знижується.

Мовознавці зазначають, що в українській мові біблійні власні назви мають потужний дериваційний потенціал, оскільки утворюють багато похідних. Цьому сприяли висока частотність їхнього вживання, важливість для носіїв мови позначуваної ними сфери, можливість накладання біблійного переносного значення на вже наявні лексичні значення, набуття символічного значення власною назвою (Скаб, 2014b, с. 246). Одним з промовистих прикладів вияву потужних дериваційних можливостей $€$ бібліїзм Хам, що означає:

1. заст. Зневажлива назва людини з нижчих соціальних верств, станів (у мові панівних класів). 2. розм., лайл. Зухвала, груба, нахабна людина // Грубе звертання до кріпака, слуги, наймита. 3. За Біблією - непутящий син благочестивого Ноя, що поглумився над своїм батьком і був ним проклятий (Бусел, 2009, с. 1555)

і має в українській мові 17 похідних (хамів, хамка, хамний, хамство, хамло, хамлюга, хамрило, хамрій, хамула, хамулуватий, хамуватий, 
хамуватість, хамувато та ін.), що наслідують переважно семантику другого значення мотиватора (Скаб, 2016, с. 16).

Отже, у цьому разі простежуємо розширення значення бібліїзму, розшарування його структури. Утім, як доводить В. Хімік, процес вияву дериваційних потенцій цього бібліїзму, а відтак і творення нових лексико-семантичних варіантів, триває. На думку цього науковця, розвитку семем у лексемі хам передувало чотири етапи:

перший - міфологічний, що пов'язаний з прецедентною ситуацією, описаною в Біблії;

другий - соціально-класовий, де прецедентне власне ім'я Хам переходить до класу загальних унаслідок метонімічного перенесення на назву соціального типу в значенні 'раб, простолюдин, холоп', що, зокрема, відбито в деяких українських пареміях, напр.: 3 хама не зробиш пана; Нема гірше з хама пана;

третій - етичний, коли розширення соціального змісту слова хам та його похідних спричинилося до мотивованого метафоричного переносу, що дефініюється як 'зухвала, груба, нахабна людина' і, відповідно, 'властивий хамові', 'зверхній, пихатий', 'схильний до хамства, зухвалий, грубий, нахабний’ тощо. Саме на цьому етапі, що співвідноситься з першою третиною ХХ століття, з'явилася фразеологічна одиниця трамвайний хам, яку використовують, коли говорять 'про пересічного побутового грубіяна, що затіває сварки в громадських місцях'. Отже, «біблійний Хам перетворився на хама трамвайного, а історичне й соціально-класове хамство стало хамством етичним» (Химик, 2014, с. 402).

За спостереженнями В. Хіміка, четвертий етап розвитку семантики слова хам і більшості його похідних - соціально-психологічний (моральний), що становить комунікативний феномен, оскільки цей поступ семантики пов'язаний з абстрактним іменником хамство, значення якого - 'вияв демонстративної зневаги, неповаги мовленнєвого партнера, вираженої в словах, жестах, діях або в їхній відсутності. Цей похідний ЛСВ значення слова хам можна дефініювати як 'людина, яка образливо порушує комунікаційні права адресата, демонструє зневагу, зверхність відносно мовленнєвого партнера', тоді як семи 'грубість', 'нахабство' зазнають деактуалізації й відходять на периферію, у чому й полягає додаткове прагматичне нарощення 
до етичного (етикетного) значення слова хам (Химик, 2014, с. 402), наприклад: Він говорив тише з нею, не звертав уваги на інших гостей, зауваження старших ігнорував повністю, поводився, як хам (3 усного мовлення).

У цьому разі простежуємо складний механізм розширення семантичної структури лексеми Хам, поступове нарощування відповідних смислів, що перетворюються на значення літературної мови. Названий вище вчений висновковує із цього приводу:

Таким чином, біблійний Хам - міфологічний персонаж, який здійснив вражаючий історичний шлях з минулого в грядуще, залишив глибокий слід у християнській культурі, соціальних відносинах нащадків, їхніх етичних і соціально-психологічних уявленнях. «Помста Ноя» глибоко відбилася і в мовах, у всякому разі, слов'янських, у яких утворилося й активно функціює розгалужене дериваційне гніздо експресивних слів і значень ( хам, хамство, хамський...), виразних сполучень і прислів'їв, глибоких за внутрішнім комунікативно-прагматичним і філософським змістом (Химик, 2014, с. 405).

Як бачимо, у структурі наведеної лексеми відбувається не лише розширення семантики, а й виражена переінтеграція значення, коли етимологічно пряме міфологічне поступається місцем соціально-класовому, етичному й соціально-психологічному (моральному).

Німецький дослідник Й.-М. Беккер зазначає, що існує багато полісемантичних назв, які залежно від контексту можуть виступати як власна чи загальна назва. Він зауважує: «У прямому посиланні на Біблію й порівняно з індивідуальними (як реальними історичними чи такими, що ще існують, так і фіктивними) місцями й особами ці форми зберігають свою пропріальну функцію» (Беккер, 2014, с. 402), як, наприклад, у реченнях:

Це має такий вигляд, як у Содомі й Гоморрі;

Це як у Вавилоні;

Схоже на Путь на Голгобу

та ін. Однак в інших контекстах вони стають характеризувальними апелятивами, наприклад:

Він маленький Лазар ('про людину, яка страждає');

Він справжній Йов ('про людину, якій не щастить'); 
Ми тут живемо у великому Вавилоні ('про хаос');

Це намі содом і гоморра ('про грішне місце')

та ін., тобто, коли мовець уживає порівняння як у Содомi, він натякає на конкретне й індивідуальне місце й порівнює біблійну історію з реальною ситуацією. Коли ж мовець позначає певне місце або ситуацію цим словом, то воно «з його біблійними індивідуальними семантичними ознаками стає апелятивом із загальними ознаками й синонімом таких слів, як безлад, хаос, балаган, бедлам, місие розпусти тощо» (Беккер, 2014, с. 403). У такому разі цей топонім «класифікує низку місць або ситуацій, що можуть порівнюватися з першим, класичним, з біблійним містом Содом» (Беккер, 2014, с. 403), тобто відбувається депропріалізація - виникнення апелятива з імені.

Учені Й.-М. Беккер (Беккер, 2014, с. 409), Є. Отін (Отин, 2004, с. 5) указують на незавершеність цього процесу й амбівалентність власних назв. Автор Словаря коннотативных собственных имен пише:

У мові художньої літератури й публіцистики, у народно-розмовному мовленні, територіальних діалектах і жаргонах зустрічаємо своєрідний прийом вторинної номінації за допомогою власних назв (онімів) з метафоричними, чи символічними, значеннями. За їхньою допомогою «переносно» іменується те, що при нейтральному стилі мовлення могло позначитися загальними назвами іменників (апелятивів). При цьому такі слова не втрачають здатності співвідношення з іншими власними назвами, сприймаються як однопорядкові (Отин, 2004, с. 5).

Думку Є. Отіна підтримує й розвиває Г. Лукаш, яка детально досліджує процеси «онімної семантичної амплітуди» (Лукаш, 2017, с. 206). Із проєкцією на оніми-бібліїзми можемо розмірковувати про вияви:

конотонімізації, за якої «онімне значення набуває пояснювальної сили», а «одна з конотативних сем переміщається в ядро значення і стає головною» (Лукаш, 2017, с. 206) і при цьому зберігається образність і зв’язок із референтом, наприклад, Содом - 'безлад', Юда - 'зрадник', Соломон - 'мудрець' та ін.;

деонімізації, за якої «онім утрачає конкретність, тобто зв’язок із індивідуальним предметом, здобуваючи тим самим здатність співвідноситися із класом однорідних об’єктів (денотатом)» (Лукаш, 2017, с. 206), наприклад: хам - 'грубіян', каїн - ‘зрадник', вавилон - ‘безлад’ та ін.; 
епонімізації - переходу онімів до розряду загальних назв (епонімів) термінологічного типу найменувань, коли зв’язок з індивідуальним об’єктом фактично втрачено, наприклад, згаданий вище фінансовий термін ефект Йосипа та ін.

Названа дослідниця наголошує, що зазначені процеси передусім спричинені конотанімізацією.

У зв’язку із цим деякі науковці стверджують наявність у власних імен ономастичної конотації, яка безпосередньо пов’язана зі здатністю власних імен, з одного боку, зберігати ономастичні ознаки, а з другого деонімізуватися (депропріалізуватися). Лінгвісти зауважують, що, як правило, «за подібними власними іменами стоїть більша інформація, яка збуджує у свідомості людей різноманітні образи й асоціації» (Лапицкая, 2005, с. 171).

Як видається, закріпленню за біблійною власною назвою тієї чи тієї ономастичної конотації сприяє ії̈ вживання у складі компаративних зворотів, що, зрештою, впливає й на їхню здатність виражати оцінку. О. Сафронова зазначає, що компаративні бібліїзми «мають яскраво виражений оцінний характер, чому сприяє структура, лексична наповненість цих зворотів, а також вербалізація предмета, який лежить в основі порівняння. Позитивна чи негативна оцінка виразу залежить від семантики першого компонента звороту» (Сафронова, 1997, с. 55), наприклад: бідний як Лазар, старий як Адам, терплячий як Йов та ін. Як видається, таке твердження не може бути абсолютно беззаперечним, оскільки оцінне значення й іронічна конотація таких компаративних бібліїзмів, як

вірний як Іуда в середу - 'невірний, зрадливий',

сміливий як святий Петро - 'боягуз',

винуватий як Христос перед жидами - 'зовсім не винуватий'

та ін., не мотивуються першим компонентом, а створюються в мовній грі, адже, як зауважує I. Кузнецова, «доволі часто мовна гра у стійких порівняннях створюється внаслідок антонімії планів змісту й вираження» (Кузнецова, 2013, с. 124). Очевидно, простежуємо формування енантеосемії: наприклад, зафіксований І. Франком компаративний зворот Премудрий як Саламон (Пилипчук, 2006, с. 784) означає не розумну людину, а, навпаки, таку, яка вдає із себе мудру, тому й зворот уживається 
з іронічною конотацією. Ще більш яскраво така розбіжність між значенням першого компонента фразеологічної одиниці й змістом загалом виявляється в периферійних бібліїзмах, у складі яких $є$ відонімне утворення, наприклад, присвійний прикметник, поєднаний з відповідною побутовою назвою, порівн.: розумний, як Соломонів патинок - 'дурний' (Бусел, 2009, с. 710).

Як було зазначено, у сучасній українській мові біблійним антропонімам властива не лише семантична, а й конотативна амплітуда, коли вони отримують протилежну конотацію. Так, скажімо, розглядуване вище прецедентне біблійне ім'я Мойсей унаслідок використання в сучасному російському мультфільмі про трьох богатирів (Алеша Попович и Тугарин Змей та ін.) і, відповідно, у його українських перекладах, як найменування дурнуватого віслюка, що водив за собою головних героїв, аж ніяк не сприяє позитивному сприйняттю образу біблійного пророка у свідомості молодого покоління - основної аудиторії цього мультфільму. Про «деградацію високих імен» говорить і В. Мокієнко, що зумовлене активним перепадом високого й низького, рухом від патетики до насмішки (Мокиенко, 2010, с. 7).

Отже, біблійні антропоніми й топоніми, що функціюють у сучасній українській літературній мові, мають потужний стильовий потенціал: вони вживаються фактично в усіх, окрім офіційно-ділового, функційних стилях, щоправда, не з однаковою активністю. У мові спостерігаємо наслідки взаємодії сакрального й профанного, унаслідок чого досліджувані власні назви зазнають різних виражень десакралізації й ресакралізації. Сполучена ресакралізація біблійних власних назв $є$ потужним експресивним засобом, особливо при вживанні в сильних заголовкових текстових позиціях.

Переважна більшість досліджуваних одиниць $є$ прецедентними, тому набувають статусу символем. При цьому значна їхня частина апелятивізується, виявляючи до того ж ономастичну конотацію. Семантична й конотативна амплітуди біблійних онімів доволі широка, що $€$ предметом мовної гри, унаслідок якої в деяких одиниць розвивається не лише полісемія, а й енантеосемія.

Перспективним видається дослідження функціювання біблійних власних назв у сучасній українській мові з огляду на їхній дериваційний потенціал і прецедентність. 


\section{Бібліографія}

Бабич, Н. (1994). Теоніми у буковинській фразеології. In Д. Бабич \& О. Бабич (Eds.), Українська мова на Буковині: Матеріали Всеукраїнської наукової конференції, присвяченої 160-річчю від дня народження Ю. Федьковича (pp. 70-72). Чернівецький національний університет.

Безпалова, Е. (2015). Особенности использования сакральной лексики в текстах традиционной и альтернативной проповеди. Записки з романо-германської білологіï, 2015(2(35)), 10-17.

Беккер, Й.-М. (2014). Как слова становятся именами, а имена словами? In M. Aleksiejenko (Ed.), Słowo, tekst, czas: Vol. 12. Frazeologia w idiolekcie i systemach języków słowiańskich: W 200. rocznicę urodzin Tarasa Szewczenki (Vol. 2, pp.401-410). Volumina.pl Daniel Krzanowski.

Берест, Т. (2000). Семантика художнього слова в поезії 80-90-х років ХХ століття [Unpublished summary of doctoral dissertation]. Харківський національний університет ім. В. Н. Каразіна.

Берестова, А. (2016). Релігійна прецедентність у мові української прози кіния ХХ початку ХХІ століття [Unpublished summary of doctoral dissertation]. Харківський національний педагогічний університет ім. Г. С. Сковороди.

Бетехтина, Е. (1999). Фразеологизмы с библейскими именами в русском и английском языках. Издательство Санкт-Петербургского университета.

Білоноженко, В., Гнатюк, І., Дятчук, В., Неровня, Н., \& Федоренко, Т. (2008). Словник фразеологізмів украйнської мови. Наукова думка.

Бусел, В. (Еd.). (2009). Великий тлумачний словник сучасної української мови. ВТФ “Перун”.

Гонтарук, Л. (2011). Сфера сакрум - профанум у системі культура - мова. Вісник Львівського університету: Серія філологічна, 2011(52), 46-58.

Дзера, О. (2017). Біблійна інтертекстуальність і переклад: Англо-украйнський контекст. Львівський національний університет ім. Івана Франка.

Добош, О. (2017). Аналіз біблеїзмів: Стилістична і прагматична функції: На матеріалі промов українського президента П. Порошенка та 44-го президента США Б. Обами. In O. Левченко (Ed.), Людина, комп'ютер, комунікація: Збірник наукових праць (рp. 158-163). Видавництво Львівської політехніки.

Дубровина, К. (2012). Библейские фразеологизмы в русской и европейской культуре. Флинта.

Задорожний, В. (1998). До проблеми розвитку конфесійного стилю сучасної української літературної мови. In М. Петрович (Ed.), Сучасна украӥнська богословська термінологія: Від історичних традицій до нових концепцій: Матеріали Всеукраїнської наукової конференції (рp. 134-145). Львівська богословська академія.

Карпенко, О. (2006). Проблематика когнітивної ономастики. Астропринт.

Коваль, А. (2012). Спочатку було Слово: Крилаті вислови біблійного походження в українській мові. Либідь. 
Ковтун, А. (2011). Багатство релігійної та церковної лексики у творах Бориса Харчука. Наукові записки Тернопільського національного педагогічного університету імені Володимира Гнатюка, 33, 314-323.

Кочан, I. (2005). Функції газетних заголовків. Лінгвістичні дослідження: Збірник наукових праць Харківського національного педагогічного університету ім. Г. С. Сковороди, 2005(16), 128-135.

Кузнецова, И. (2013). Языковая шутка в устойчивых сравнениях с персонажем Библии. In H. Walter (Ed.), Славянская фразеология и Библия (pp. 123-129). Ernst Moritz Arndt Universität Greifswald.

Лапицкая, Н. (2005). Ономастическая коннотация в устойчивых выражениях. In В. Коваль (Еd.), Славянская фразеология в ареальном, историческом и этнокультурном аспектах: Материалы IV Международной научной конферениии (рр. 169-172). Гомельский государственный университет им. Ф. Скорины.

Лукаш, Г. (2017). Амплітуда семантичного розширення власних назв. Наукові записки Тернопільського національного педагогічного університету імені Володимира Гнатюка: Мовознавство, 2017 (1(27)), 204-209.

Мокиенко, В. (2010). Перевоплощенное имя. In Е. Отин (Ed.), Словарь коннотативных собственных имен (pp. 5-10). Юго-Восток ЛТД.

Мокиенко, В. (2014). Фразеологические библеизмы: непонятное в понятном. In M. Aleksiejenko (Ed.), Słowo, tekst, czas: Vol. 12. Frazeologia w idiolekcie i systemach języków słowiańskich: W 200. rocznicę urodzin Tarasa Szewczenki (Vol. 2, pp. 414-429). Volumina.pl Daniel Krzanowski.

Німчук, В. (1993). Українська мова - священна мова. Людина і світ, 1993 (11-12), 26-31.

Отин, Е. (2004). Словарь коннотативных собственных имен. Юго-Восток ЛТД.

Пилипчук, C. (Ed.). (2006). Галицько-руські народні приповідки (Vol. 3). Видавничий центр Львівського національного університету ім. I. Франка.

Сафронова, О. (1997). Біблійні власні назви у складі ад'єктивних компаративних фразеологічних одиниць: На матеріалі сучасної англійської мови. Мовознавство, 1997(4-5), 52-57.

Скаб, М. (2010). Основні напрями дослідження взаємодії української мови і сфери сакрального: Здобутки та перспективи. Науковий вісник Чернівецького національного університету імені Юрія Федьковича: Слов'янська філологія, 2010 (506-508), 3-10.

Скаб, М. (2014а). Біблійні алюзії у збірці Богдана Мельничука На ріках вавилонських. Науковий вісник Чернівецького національного університету імені Юрія Федьковича: Романо-слов'янський дискурс, 2014(732-733), 178-181.

Скаб, М. (2014b). Дериваційні потенції біблійних крилатих слів і виразів як засіб виявлення української мовної картини світу. In M. Вінтонів (Ed.), Мовний простір граматики: Актуальні студї: Збірник наукових праць на честь 60-річчя член-кореспондента НАН України Анатолія Загнітка (рр. 242-247). Донецький національний університет. 
Скаб, М. (2016). Вплив Біблії на українську мову: Обшир, аспекти та основні проблеми їх вивчення. Науковий вісник Чернівецького національного університету імені Юрія Федьковича: Романо-слов'янський дискурс, 2016(772), 13-20.

Солошенко, О. (1999). Про визначення і типологію біблеїзмів. Іноземна філологія: Український науковий збірник, 1999(111), 132-138.

Софронова, Л. (2006). Культура сквозь эпоху поэтики. Языки славянских культур.

Тимошик, Г. (2009). Давньогрецькі жіночі імена у новозавітному тексті: На матеріалі новочасних перекладів Святого письма українською мовою. Гуманітарна освіта в технічних вищих навчальних закладах, 2009(18), 63-67.

Тимошик, Г. (2010). Біблієантропоніми в новочасних перекладах Святого Письма українською мовою. Львівський національний університет ім. І. Франка.

Химик, В. (2014). Библейский Хам и хам трамвайный: Семантико-прагматическая история. In M. Aleksiejenko (Ed.), Słowo: Tekst: Czas: Vol. 12. Frazeologia w idiolekcie i systemach języków słowiańskich: W 200. rocznicę urodzin Tarasa Szewczenki (Vol. 1, pp. 400-406). Volumina.pl Daniel Krzanowski.

Хлебда, В. (2001). Десакрализация и ресакрализация библейской фразеологии в русской печати последнего десятилетия. Studia Rossica Posnaniensia, 29, 123-130.

\section{Bibliography (Transliteration)}

Babych, N. (1994). Teonimy u bukovyns'kiü frazeolohiï. In B. Babych \& O. Babych (Eds.), Ukraïns'ka mova na Bukovyni: Materialy Vseukrä̈n'kö̈ naukovoï konferentsï, prysviachenoï 160-richchiu vid dnia narodzhennia Yu. Fed'kovycha (pp. 70-72). Chernivets'kyĭ natsional'nyı̌ universytet.

Bekker, Ĭ.-M. (2014). Kak slova stanoviatsia imenami, a imena slovami? In M. Aleksiejenko (Ed.), Słowo, tekst, czas: Vol. 12. Frazeologia w idiolekcie i systemach języków słowiańskich: W 200. rocznice urodzin Tarasa Szewczenki (Vol. 2, pp.401-410). Volumina.pl Daniel Krzanowski.

Berest, T. (2000). Semantyka khudozhn'oho slova v poezii 80-90 rokiv XX stolittia [Unpublished summary of doctoral dissertation]. Kharkivs'kyı̆ natsional'nyı̆ universytet im. V. N. Karazina.

Berestova, A. (2016). Relihǐna pretsedentnist' u movi ukraïns'koï prozy kintsia XX - pochatku XXI stolittia [Unpublished summary of doctoral dissertation]. Kharkivs'kyı̆ natsional'nyı̆ universytet im. H. S. Skovorody.

Betekhtina, E. (1999). Frazeologizmy s bibleǔskimi imenami: V russkom i angliǔskom iazykakh. Izdatel'stvo Sankt-Peterburgskogo universiteta.

Bezpalova, E. (2015). Osobennosti ispol'zovaniia sakral'noŭ leksiki v tekstakh traditsionnoŭ i al'ternativnoĭ propovedi. Zapysky z romano-hermans'koï filolohii, 2015(2(35)), 10-17.

Bilonozhenko, V., Hnatiuk, I., Diatchuk, V., Nerovnia, N., \& Fedorenko, T. (2008). Slovnyk frazeolohizmiv ukraïns'koï movy. Naukova dumka. 
Busel, V. (Ed.). (2009). Velykyı̆ tlumachnyı̆ slovnyk suchasnoï ukraïns'koï movy. VTF "Perun”.

Dobosh, O. (2017). Analiz bibleïzmiv: Stylistychna i prahmatychna funktsiï: Na materiali promov ukraïns'koho prezydenta P. Poroshenka ta 44-ho prezydenta SShA B. Obamy. In O. Levchenko (Ed.), Liudyna, komp'iuter, komunikatsiia: Zbirnyk naukovykh prats' (pp. 158-163). Vydavnytstvo Lvivs'koï politekhniky.

Dubrovina, K. (2012). Bibleı̌skie frazeologizmy v russkoŭ i evropeřskoŭ kul'ture. Flinta.

Dzera, O. (2017). Bibliı̌na intertekstual'nist' i pereklad: Anhlo-ukrä̈ns'kyı̆ kontekst. L'vivs'kyı̌ natsional'nyı̆ universytet im. Ivana Franka.

Hontaruk, L. (2011). Sfera sakrum - profanum u systemi kul'tura - mova. Visnyk L'vivs'koho universytetu: Seriia filolohichna, 2011(52), 46-58.

Karpenko, O. (2006). Problematyka kohnityvnoï onomastyky. Astroprynt.

Khimik, V. (2014). Bibleŭskiı̆ Kham i kham tramvaĭnyı̆: Semantiko-pragmaticheskaia istoriia. In M. Aleksiejenko (Ed.), Słowo, tekst, czas: Vol. 12. Frazeologia w idiolekcie i systemach języków słowiańskich: W 200. rocznicę urodzin Tarasa Szewczenki (Vol. 1, pp. 400-406). Volumina.pl Daniel Krzanowski.

Khlebda, V. (2001). Desakralizatsiia i resakralizatsiia bibleĭskoŭ frazeologii v russkoŭ pechati poslednego desiatiletiia. Studia Rossica Posnaniensia, 29, 123-130.

Kochan, I. (2005). Funktsiï hazetnykh zaholovkiv. Linhvistychni doslidzhennia: Zbirnyk naukovykh prats' Kharkivs'koho natsional'noho pedahohichnoho universytetu im. H. S. Skovorody, 2005(16), 128-135.

Koval', A. (2012). Spochatku bulo Slovo: Krylati vyslovy bibliünoho pokhodzhennia v ukraïns'kiu movi. Lybid'.

Kovtun, A. (2011). Bahatstvo relihiinnoï ta tserkovnoï leksyky u tvorakh Borysa Kharchuka. Naukovi zapysky Ternopil's'koho natsional'noho pedahohichnoho universytetu imeni Volodymyra Hnatiuka, 33, 314-323.

Kuznetsova, I. (2013). IAazykovaia shutka v ustoĭchivykh sravneniiakh s personazhem Biblii. In H. Walter (Ed.), Slavianskaia frazeologiia i Bibliia (pp. 123-129). Ernst Moritz Arndt Universität Greifswald.

Lapitskaia, N. (2005). Onomasticheskaia konnotatsiia v ustořchivykh vyrazheniiakh. In V. Koval' (Ed.), Slavianskaia frazeologiia $v$ areal'nom, istoricheskom i ètnokul'turnom aspektakh: Materialy IV Mezhdunarodnoı nauchnő konferentsii (pp. 169-172). Gomel'skiĭ gosudarstvennyı̆ universitet im. F. Skoriny.

Lukash, H. (2017). Amplituda semantychnoho rozshyrennia vlasnykh nazv. Naukovi zapysky Ternopil's'koho natsional'noho pedahohichnoho universytetu imeni Volodymyra Hnatiuka: Movoznavstvo, 2017(1(27)), 204-209.

Mokienko, V. (2010). Perevoploshchennoe imia. In E. Otin (Ed.), Slovar' konnotativnykh sobstvennykh imen (pp. 5-10). IUgo-Vostok LTD.

Mokienko, V. (2014). Frazeologicheskie bibleizmy: neponiatnoe v poniatnom. In M. Aleksiejenko (Ed.), Słowo, tekst, czas: Vol. 12. Frazeologia w idiolekcie i systemach języków słowiańskich: 
W 200. rocznice urodzin Tarasa Szewczenki (Vol.2, pp. 414-429). Volumina.pl Daniel Krzanowski.

Nimchuk, V. (1993). Ukraïns'ka mova - sviashchenna mova. Liudyna i svit, 1993(11-12), 26-31.

Otin, E. (2004). Slovar' konnotativnykh sobstvennykh imen. IUgo-Vostok LTD.

Pylypchuk, S. (Ed.). (2006). Halyts'ko-rus'ki narodni prypovidky (Vol. 3). Vydavnychyı̆ tsentr L'vivs'koho natsional'noho universytetu im. I. Franka.

Safronova, O. (1997). Bibliǔni vlasni nazvy u skladi ad'iektyvnykh komparatyvnykh frazeolohichnykh odynyts': Na materiali suchasnoï anhliǐs'koï movy. Movoznavstvo, 1997(4-5), 52-57.

Skab, M. (2010). Osnovni napriamy doslidzhennia vzaiemodiï ukraïns'koï movy i sfery sakral'noho: Zdobutky ta perspektyvy. Naukovyı̆ visnyk Chernivets'koho natsional'noho universytetu imeni IUriia Fed'kovycha: Slov'ians'ka filolohiia, 2010(506-508), 3-10.

Skab, M. (2014a). Bibliŭni aliuziï u zbirtsi Bohdana Melnychuka Na rikakh vavylons'kykh. Naukovyı visnyk Chernivets'koho natsional'noho universytetu imeni IUriia Fed'kovycha: Romano-slov'ians'ky̌̆ dyskurs, 2014(732-733), 178-181.

Skab, M. (2014b). Deryvatsiŭni potentsiï bibliǔnykh krylatykh sliv i vyraziv iak zasib vyiavlennia ukraïns'koï movnoï kartyny svitu. In M. Vintoniv (Ed.), Movny̌ prostir hramatyky: Aktual'ni studii: Zbirnyk naukovykh prats' na chest' 60-richchia chlen-korespondenta NAN Ukraïny Anatoliia Zahnitka (pp. 242-247). Donets'kyı̆ natsional'nyı̆ universytet.

Skab, M. (2016). Vplyv Bibliï na ukraïns'ku movu: Obshyr, aspekty ta osnovni problemy ïkh vyvchennia. Naukovyı visnyk Chernivets'koho natsional'noho universytetu imeni IUriia Fed'kovycha: Romano-slov'ians'kyi dyskurs, 2016(772), 13-20.

Sofronova, L. (2006). Kul'tura skvoz' épokhu poètiki. IAzyki slavianskikh kul'tur.

Soloshenko, O. (1999). Pro vyznachennia i typolohiiu bibleïzmiv. Inozemna filolohiia: Ukraïns'kyı̆ naukovyi zbirnyk, 1999(111), 132-138.

Tymoshyk, H. (2009). Davn'ohrets'ki zhinochi imena u novozavitn'omu teksti: Na materiali novochasnykh perekladiv Sviatoho pys'ma ukraïns'koiu movoiu. Humanitarna osvita v tekhnichnykh vyshchykh navchal'nykh zakladakh, 2009(18), 63-67.

Tymoshyk, H. (2010). Bibliieantroponimy v novochasnykh perekladakh Sviatoho Pys'ma ukraïns'koiu movoiu. L'vivs'kyĭ natsional'nyı̆ universytet im. I. Franka.

Zadorozhnyı̆, V. (1998). Do problemy rozvytku konfesiǔnoho styliu suchasnoï ukraïns'koï literaturnoï movy. In M. Petrovych (Ed.), Suchasna ukraïns'ka bohoslovs'ka terminolohiia: Vid istorychnykh tradytsiu do novykh kontseptsiü: Materialy Vseukraïns'koï naukovoï konferentsii (pp. 134-145). L'vivs'ka bohoslovs'ka akademiia. 


\title{
Biblical Anthroponyms and Toponyms in the Ukrainian Language: Basic Vectors of Research Development
}

\author{
Summary
}

This article considers the main features of the functioning and development of biblical anthroponyms in the modern Ukrainian language. On the one hand, proper names associated with religion serve to reflect the religious map of the world; on the other - they undergo desacralization and resacralization. This means that their pragmatic potential can expand and they can acquire non-religious semantics.

As precedent names, biblical anthroponyms and toponyms reveal their pragmatic potential, first of all, in the belles-lettres style. Despite the conservatism of academic style, biblical anthroponyms function there as well, enriching scientific terminology. In the publicist style, biblical proper names are often used in strong text positions of headings. Most of the analysed units are used as symbols. Semantic and connotative amplitudes of biblical onyms are so wide that they have become the object of word game resulting in polysemy of some units and even their enantiosemy.

\section{Biblijne antroponimy i toponimy w języku ukraińskim - główne kierunki rozwoju}

\author{
Streszczenie
}

W artykule analizuje się podstawowe cechy funkcjonowania i rozwoju biblijnych nazw osobowych we współczesnym języku ukraińskim. Nazwy własne związane z religią z jednej strony służą do odzwierciedlenia religijnego obrazu świata, z drugiej strony są poddawane desakralizacji i resakralizacji. Proces ten stwarza możliwość rozszerzenia ich potencjału pragmatycznego i uzyskania przez nie semantyki pozareligijnej. 
Biblijne antroponimy i toponimy stanowiące precedensowe nazwy własne realizują swój potencjał przede wszystkim w stylu literackim. Pomimo konserwatyzmu charakterystycznego dla stylu naukowego także w nim funkcjonują biblijne antroponimy i toponimy, które wzbogacają terminologię naukową. Biblijne nazwy własne w stylu publicystycznym są często wykorzystywane w wyrazistych tekstowych pozycjach nagłówków. Większość przeanalizowanych jednostek spełnia rolę symbolu. Semantyczne i konotacyjne amplitudy biblijnych onimów są na tyle pojemne, że stały się obiektem gry słownej prowadzącej do wieloznaczności, a nawet enancjosemii niektórych jednostek.

Keywords: biblical anthroponyms; biblical toponyms; biblical words and expressions; sacralization; desacralization; resacralization

Słowa kluczowe: antroponimy biblijne; toponimy biblijne; biblizmy; sakralizacja; desakralizacja; resakralizacja

Nataliya V. Piddubna, H. S. Skovoroda Kharkiv National Pedagogical University, Kharkiv, Ukraine ORCID: https://orcid.org/0000-0003-0331-0496

Correspondence: piddubnan71@gmail.com

The preparation of this article was self-financed by the author.

Competing interests: The author has declared that she has no competing interests.

Publication history: Received: 2019-08-20; Accepted: 2020-02-01; Published: 2021-11-28 